\title{
Disentangling structural patterns of natural forest fragments in a savanna matrix in the eastern Brazilian Amazon
}

\author{
Iêda Leão do AMARAL ${ }^{1 *}$, William Ernest MAGNUSSON ${ }^{1}$, Francisca Dionízia de Almeida MATOS ${ }^{1}$, \\ Ana Luisa K. ALBERNAZ2², Yuri Oliveira FEITOSA ${ }^{1}$, Jean-Louis GUILLAUMET ${ }^{3}$ \\ 1 Instituto Nacional de Pesquisas da Amazônia, Coordenação de Pesquisa em Biodiversidade, Caixa Postal 2223, CEP 69.080-971, Manaus, AM, Brasil. \\ 2 Museu Paraense Emílio Goeldi, Coordenação de Ciências da Terra e Ecologia, Campus de Pesquisa, Av. Perimetral 1901, CEP 66.077-530, Terra Firme, Belém, PA, Brasil. \\ ${ }^{3}$ Muséum National d'Histoire Naturelle, Laboratoire de Phanérogamie, 16, rue Buffon, 75005 Paris, França \\ * Corresponding author: iamaral@inpa.gov.br
}

\section{ABSTRACT}

Natural fragments are an important source of richness for the management and conservation of a local flora. The objective of this study was to evaluate the effect of fragmentation on the structure and composition of the plant communities of forest fragments (FF) in Alter do Chão, eastern Brazilian Amazonia. The study sample consisted of 25 FF and nine continuous forest (CF) sites. We compared plant density and species richness between site categories by t-tests, analyzed the differences in composition by cluster analysis, and assessed the effect of fragment size and distance to CF on the basal area and diameter of FF assemblages by linear regression. Individual trees and shrubs with $\mathrm{DBH} \geq 1.27 \mathrm{~cm}$ were measured in $2 \times 250 \mathrm{~m}$ plots. 17,078 individuals were recorded $-75.32 \%$ in FF and 24.68\% in CF, comprising 475 species, 216 genera and 64 families. Myrtaceae and Fabaceae were the most abundant families in both FF and CF. Average species richness in FF and CF was statistically different. The 20 species with the highest importance values were similar in FF and CF. The average plant diameter was similar in FF and CF, suggesting that both are "mature" forests composed of thin individuals. Average diameter and total basal area showed a negative relationship with distance to CF and fragment area, respectively. Similarity analysis revealed two groups, one composed exclusively of portions of fragmented forest. Fragments and continuous forest differed in species composition, but were similar in structure. Diameter distribution in fragments was similar to that of primary forests.

KEYWORDS: Bray-Curtis, Cluster analysis, diameter structure, small trees.

\section{Desvendando padrões estruturais de fragmentos florestais na Amazônia Oriental}

\section{RESUMO}

Fragmentos naturais constituem importante fonte de recursos para o manejo e conservação da flora local. Este trabalho avaliou o efeito da fragmentação sobre a estrutura e a composição das comunidades de plantas de fragmentos florestais (FF), em Alter do Chão, na Amazônia oriental brasileira. Foram amostrados 25 sítios em FF e nove em floresta contínua (CF). Analisamos a diferença na densidade de plantas e na riqueza de espécies entre FF e CF por teste-t, e na composiçáo por análise de agrupamento. Utilizou-se regressão linear para avaliar o efeito do tamanho dos fragmentos e distância à CF sobre a área basal e diâmetro. Os indivíduos com DAP $\geq 1,27 \mathrm{~cm}$ foram medidos em parcelas de 2x250 m. Foram registrados 17.078 indivíduos, 75,32\% nos FF e 24,68\% na CF, distribuídos em 475 espécies, 216 gêneros e 64 famílias. As famílias Myrtaceae e Fabaceae foram as mais abundantes em ambos FF e CF. A riqueza média diferiu significativamente entre FF e CF. As 20 espécies com maior valor de importância foram semelhantes nos FF e CF. O diâmetro médio nos FF e CF foi semelhante, sugerindo tratar-se em ambos casos de florestas "maduras" compostas por indivíduos finos. O diâmetro médio e a área basal total mostraram relação negativa com a distância à CF e área dos fragmentos, respectivamente. A análise de similaridade revelou dois grupos, um deles composto exclusivamente por fragmentos. Composicionalmente, os fragmentos diferiram da floresta contínua, sendo estruturalmente semelhantes entre si, evidenciando distribuição diamétrica semelhante à das florestas primárias.

PALAVRAS CHAVES: Bray-Curtis, análise de grupamento, estrutura diamétrica, pequenas árvores. 


\section{INTRODUCTION}

Forest fragmentation is the result of either natural or anthropic processes that can divide or reduce large areas of existing forest cover into smaller, disjunct, parts (Cerqueira $e t$ al. 2003). Fragmented habitats or islands of different habitats can be produced by a variety of natural processes, which must be distinguished if fragment composition is to be correctly interpreted. Forest islands are isolated forest fragments, found in open areas of savanna-forest contact zones in the Neotropics (Huber et al. 2006).

Old natural fragments have served as source material for restoration and have important role in the planning, management and conservation of native local flora. As well as being essential for the development of rational strategies for use of natural resources, they help maintain water quality and prevent erosion (Peters et al. 1989), especially when embedded in the savanna matrix.

The Amazon region also contains some very old forest fragments, their generating processes being a matter of debate among researchers. Alter do Chão, Pará State, has natural forest fragments within savanna areas. Their origin is unclear, given that 4000 years ago the whole region was covered by continuous forest and there are no obvious differences in the topography or soil characteristics between the fragments and the surrounding savanna (Sanaiotti et al. 2002). Some authors suggest that such forest fragments may have been caused by fires set by Amerindians, which could have favored the establishment and subsequent perpetuation of grasslands in forest areas in the Amazon (Serena 1984), or that they may have been produced by other processes, including natural climatic fluctuations, soil heterogeneities, topographic variation, river and sea hydrodynamics and hydrological processes in periodically flooded areas (Constantino et al. 2003).

There is very little information about the diversity, floristic composition and structure of forest fragments within Amazonian savannas (Prado 2000), although there are reports concerning the influence of topography, soil and watercourse proximity on their composition, richness and diversity (Sette-Silva 1997). According to Tabarelli et al. (2004), fragmentation does not occur in isolation, and its effect will be amplified when associated with the synergistic effects of other events threatening tree cover in neotropical forests.

The forest fragments in Alter do Chão were scientifically documented for the first time by Bates (1892), who described them as forest islands, insular in form and distribution and surrounded by grass. The antiquity of the forest fragments in Alter do Chão provides an opportunity to study the composition and the structure of forest patches that have been isolated for a long time and compare them to continuous forest in the same region. Thus this study aimed at investigating whether differences existed between plant structure and species composition of the forest fragments and continuous forest in Alter do Chão, and the relation of fragment area and distance from continuous forest with these parameters.

\section{MATERIALS AND METHODS}

\section{Study area}

Situated on the right bank of the Tapajós River, the Alter do Chão district (centered on $2^{\circ} 31^{\prime} \mathrm{S}$ and $55^{\circ} 00^{\prime} \mathrm{W}$ ) occupies an area of approximately $1,706 \mathrm{~km} 2$ and lies some $30 \mathrm{~km}$ from Santarém, Pará State, Brazil. The area has isolated forest fragments lying within a savanna matrix, as well as a large area of continuous native forest (Figure 1). The climate is Am, according to the Köppen classification, characterized as being hot and humid, with a dry period between July-November, with September being the driest month $(34 \mathrm{~mm}$ average precipitation). The rainy season lasts from January to June, with April being the wettest month (346 mm precipitation). On average, five months have less than $100 \mathrm{~mm}$ rainfall (range $34-85 \mathrm{~mm}$ ). Average annual rainfall is $1,991 \mathrm{~mm}$, and average annual temperature $25.9^{\circ} \mathrm{C}$ (range $20.2-32.2^{\circ} \mathrm{C}$ (Climatedata.org 2014).

At Alter do Chão, dense terra firme rainforest occupies the higher regions, and open rainforest with palm trees occupies lower-lying areas. Seasonally-flooded forest (igapó) occurs close to water bodies. There are also continuous strips of white sand beaches along the margins of rivers and tributaries. Savanna vegetation occurs in many areas, and is composed of a graminoid-dominated landscape, interspersed with shrubs and trees with twisted trunks, most with thick bark, large canopies and leathery leaves (Miranda 1993). At the study site, the savanna is surrounded by tropical semi-deciduous forest (IBGE 2012) which also forms the forest fragments, known locally as "ilhas de mata" (forest islands) that lie within the savanna. Secondary vegetation occurs in areas where human activities, such as agriculture and logging, have occurred. Even after many years of regeneration, these are still structurally different from the primary forest (Albernaz 2001).

\section{Data collection}

Data were collected from 1998 to 2001 in forest fragments (FF) and continuous forest (CF) composed of Semi-deciduous Forest (IBGE 2012). The area, perimeter and degree of isolation of fragments were calculated from Landsat satellite TM-5 images, orbits/point 227/62 1999, to identify forests, with fragment profiles converted to vector format and their areas calculated in ArcView 3.2 software (ESRI 1996). The continuous-forest area sampled covered hundreds of hectares and the sampling units were established between 1-10 kilometers from each other. 


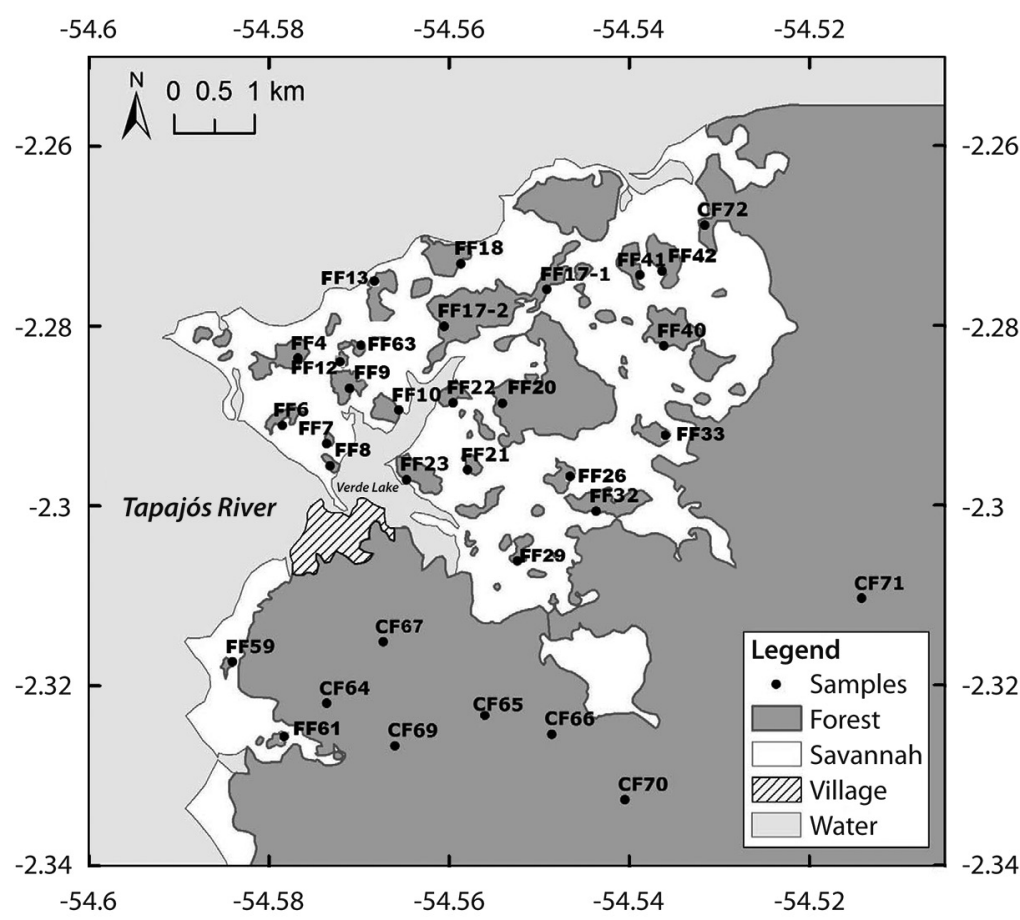

Figure 1. Map of part of the Alter do Chão region, Santarém, Brazil, showing the distribution of forests, savannas, the town of Alter do Chão, the major water bodies and the location (in black) of sample sites. $\mathrm{FF}=$ forest fragment, $\mathrm{CF}=$ continuous forest. (Source: Albernaz 2001).

In total 34 sampling points were analyzed; 25 in FF and nine in CF. Within all nine CF sites and 23 of $25 \mathrm{FF}$ sites, four subplots of $2 \mathrm{~m} \times 250 \mathrm{~m}\left(2000 \mathrm{~m}^{2}\right)$ were established. The exceptions were two very small fragments where only two subplots $\left(1000 \mathrm{~m}^{2}\right)$ were established. The subplots were arranged perpendicular to the fragment edge, $50 \mathrm{~m}$ apart from it, and parallel to each other, separated by $50 \mathrm{~m}$.

Individual trees and shrubs with a minimum of $4 \mathrm{~cm}$ in circumference at breast height (CAP), corresponding to 1.27 $\mathrm{cm}$ in diameter at breast height $(\mathrm{DBH})$ at $1.30 \mathrm{~m}$ above the ground, were measured, numbered and labeled with aluminum tags and botanical samples were collected for later species identification. Identification was carried out by morphological comparison to specimens in the Herbarium of the National Institute of Amazonian Research (INPA), as well as by consulting literature and taxon experts (see acknowledgements). Taxonomic classification of specimens followed the Angiosperm Phylogeny Group (APG III 2009), as presented in the updated classification on the group website (http://floradobrasil.jbrj. gov.br/reflora. Accessed from 12/10/2016 to 01/15/2017)). Unidentified botanical samples were morphotyped to the lowest possible taxon level and reference material was incorporated into the INPA herbarium collection. Further information on the complete species list is available at http://ppbio.inpa.gov. $\mathrm{br} / \mathrm{knb} /$ metacat?action=read \&qformat=ppbio $\&$ sessionid $=0 \&$ docid=liliandias. 91.1

\section{Data analysis}

Plant density, species richness and DBH distribution were compared between FF and CF using t-tests in the R statistical platform (R Core Team 2014). Phytosociological parameters were estimated following Mueller-Dombois and Ellemberg (2003). For this, forest fragments (FF) were categorized into small (SF), medium (MF) and large (LF), based on the mean area of the fragments $(44.62 \mathrm{ha})$; where fragments with an area below $50 \%$ of the average value $(2.4-22.34 \mathrm{ha}, \mathrm{N}=13)$ were classified as small, those in the range 22.34-67.01 ha $(\mathrm{N}=10)$ as medium, and those above $67.01 \mathrm{~h}$ as large $(\mathrm{N}=2)$.

The structural profiles of forest fragments and continuous forest were analyzed as the frequency distribution of $\mathrm{DBH}$ classes. As the forest had many thin individuals, a class amplitude of $5 \mathrm{~cm}$ was adopted (Soares et al. 2007). The effect of fragment area $\left(\mathrm{F}_{\mathrm{A}}\right)$, sampled area $\left(\mathrm{S}_{\mathrm{A}}\right)$, and distance of fragments to $\mathrm{CF}\left(\mathrm{D}_{\mathrm{CF}}\right)$ on two dependent variables, mean DBH $\left(\mathrm{DBH}_{\mathrm{M}}\right)$ and total basal area $\left(\mathrm{T}_{\mathrm{BA}}\right)$, was analyzed using multiple linear regression. The difference in species composition between fragments and continuous forest was analyzed with a cluster analysis based on a matrix of relative abundance in each fragment, using an ecological distance matrix between the pairs 
of sampling units (Bray-Curtis 1957). Difference was expressed in terms of between-site variance in species content (Kindt and Coe 2005), using hierarchical clustering methods and the unweighted pair-group average (UPGM) distance algorithm for all members in the groups. Ordination was done with the PAST program - Paleontological Statistic Software Package (Hammer et al. 2001).

\section{RESULTS}

Overall 17,078 individuals were sampled, 12863 (75.32\%) in FF and $4215(24.68 \%)$ in CF. These were classified into 475 species, in 216 genera from 64 families. Out of the total number of individuals, 264 were identified only to family level. Of these, $54.54 \%$ belonged to Myrtaceae, a family difficult to identify by comparative morphology of sterile material; 479 individuals were identified only to genus level $(2.80 \%)$, and $80(0.47 \%)$ could not be identified to any taxonomic level below angiosperm.

A total of 387 species were recorded from the fragments, distributed in 185 genera from 60 families. The highest number of individuals was recorded in the SF $(6119$ individuals), followed by MF (5430) and LF (1314 individuals). In CF, the 4215 individuals recorded belonged to 320 species in 168 genera from 61 families. A t-test revealed no difference between the average plant density in the two forest environments $(\mathrm{FF}=2673.24 ; \mathrm{CF}=2330.34 ; \mathrm{t}=0.8432$, $\mathrm{df}=32, \mathrm{p}=0.405)$.

The families with the highest numbers of individuals in both forest types were Myrtaceae, Fabaceae, Salicaceae, Sapindaceae, Lauraceae and Euphorbiaceae (in descending order). Together these accounted for $46.58 \%$ of total plants sampled. Two of these families, Fabaceae and Myrtaceae, were part of the 10 most diverse families, accounted for $51.68 \%$ of overall species richness (Figure 2), and contributed 20 species that accounted for $41.75 \%$ of the total number of individuals (Figure 3). The genera Eugenia, Inga, Swartzia, Myrcia, Casearea and Miconia together contributed the highest number of species (79: $16.6 \%$ of the total). The remainder (211 genera) commonly occur in other types of vegetation in the Amazon and Atlantic Forest. Some species of Miconia, Casearea and other genera were associated with forest edges and occur in anthropogenic and natural clearings. At the edges, it was common to find Miconia and/or Casearea species, often with many juveniles.

Of the 475 species found, 113 (23.74\%) were common to both FF and CF. Of these, three had the highest densities: Ocotea longifolia Kunth (649 individuals), Casearia javitensis Kunth (623) and Myrcia splendens DC (916). Twenty species were considered generalists, with Tapirira guianensis Aubl., Handroanthus serratifolia (Vahl) S.O.Grose, Bellucia grossularioides Triana, Casearia javitensis Kunth and Simarouba

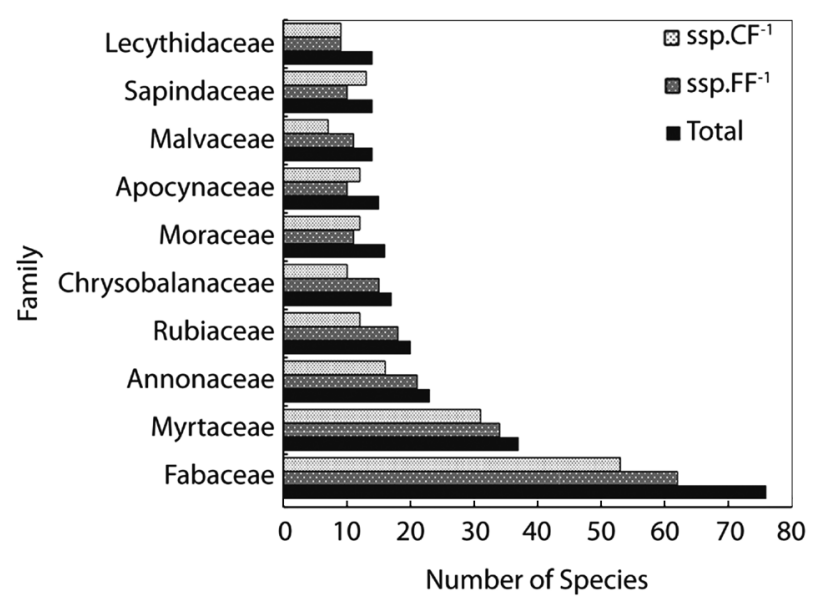

Figure 2. The 10 families with the greatest species richness in FF and CF sampling sites in Alter do Chão.

amara Aubl. being considered generalists able to prosper in a variety of environments (Cavalcanti and Tabarelli 2004). Forty species are known to occur in FF and savanna areas in other regions of the country (Northeast, Central-West and Southeast), and in Alter do Chão 33 of these were found in the FF (Magnusson et al. 2008).

Nine species (2\% of the total) are listed as vulnerable by IBAMA (2008): Bowdichia nitida Spruce, Dimorphandra parviflora Spruce ex Benth, Platymiscium trinitatis Benth, Swartzia leptopetala Benth, Swartzia macrocarpa Spruce, Mezilaurus ita-uba Taub. ex Mez, Ocotea cujumary Mart, Eschweilera micranta, Miers and Pouteria venosa (Mart.) Baehni. However, these species were abundant locally in FF and CF.

Mean species richness differed significantly between FF and $\mathrm{CF}$ assemblages at the $95 \%$ confidence level $(\mathrm{FF}=86.48$; $\mathrm{CF}=109.67 ; \mathrm{P}=0.012)$. Richness within the fragments was no greater than that between them $(P=0.24)$, but differed from continuous forest $(\mathrm{P}=0.017)$.

The phytosociological analysis of assemblages from fragments and continuous forest showed that, for the 20 species of each fragment grouped with highest IV (importance value), the relative values of density, frequency and dominance, when expressed as IV indexes, were numerically similar between environments, and deviations from the means of these parameters were small $\left(\mathrm{IV}_{20 \mathrm{spp}}=109.74+6.45 ;\right.$ Den $_{20 \mathrm{spp}}$ $=43.71+1.38 ;$ Freq $_{20 \text { spp }}=16.24+3.04 ;$ Dom $_{20 \text { spp }}=49.82$ + 4.56). Among the 20 more important species, only three had high IV scores in all environments (6.25\%). Of the other species, $18.75 \%$ occurred in LF, $16.67 \%$ in MF, $10.42 \%$ in $\mathrm{SF}$, and $16.67 \%$ in CF. The remaining $35.42 \%$ occurred in two or three of the four groups, respectively (Table 1 ).

No striking structural differences in DBH frequency distribution were found between groups. However, there were 


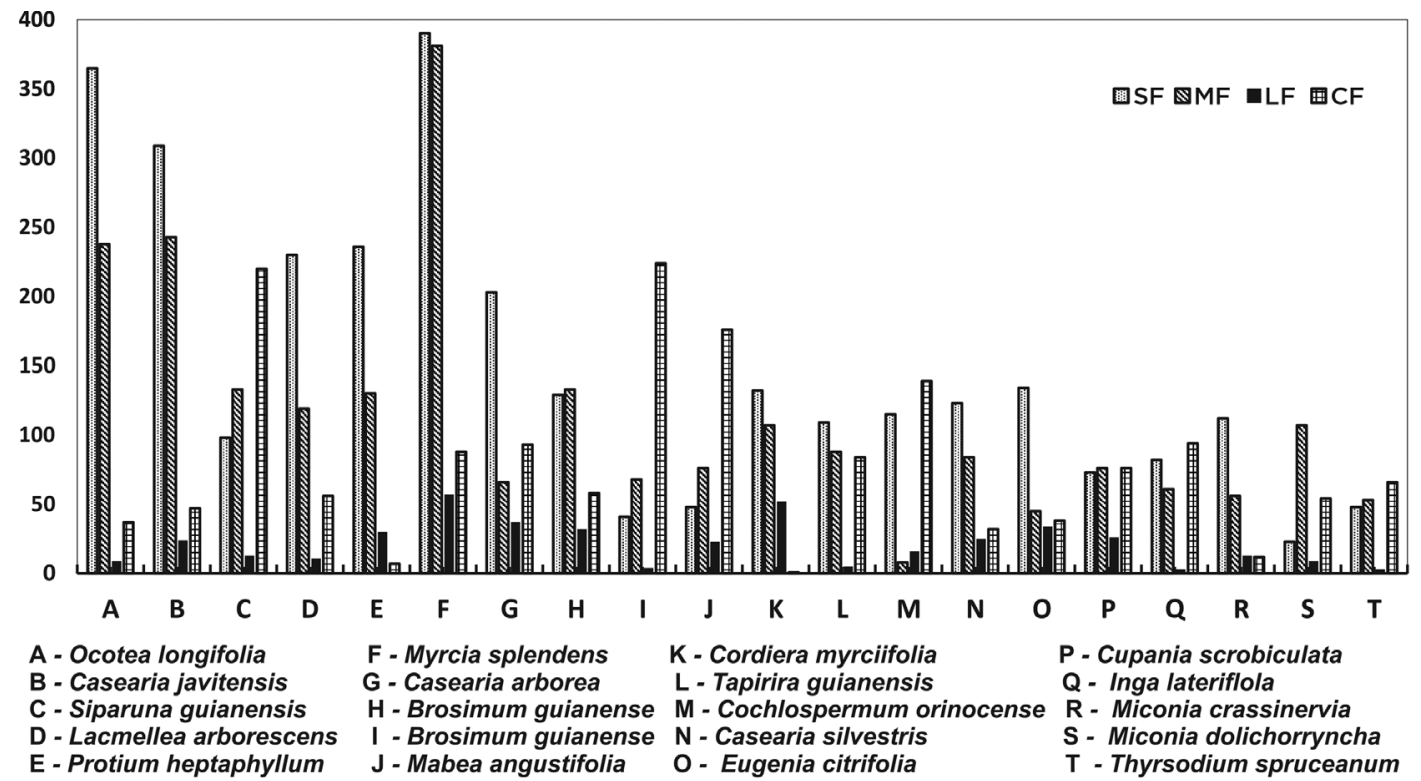

Figure 3. The 20 species with the widest distribution in forest fragments and continuous forest in Alter do Chão. SF $=$ small fragment, MF $=$ medium fragment, $\mathrm{LF}=$ large fragment, $\mathrm{CF}=$ continuous fragment.

Table 1. Phytosociological parameters for 47 species, emphasizing the 20 most important, for each sampled habitat, ordered by size of location (CF $=$ continuous forest, $\mathrm{SF}=$ small fragments, $\mathrm{MF}=$ medium fragments, $\mathrm{LF}=$ large fragments) showing Density (Den) and Importance Value (IV) estimates.

\begin{tabular}{|c|c|c|c|c|c|c|c|c|c|}
\hline \multirow[b]{2}{*}{ Species } & \multirow[b]{2}{*}{ Family } & \multicolumn{2}{|c|}{ CF } & \multicolumn{2}{|c|}{ SF } & \multicolumn{2}{|c|}{ MF } & \multicolumn{2}{|c|}{ LF } \\
\hline & & $\begin{array}{r}\text { Den } \\
(\%)\end{array}$ & $\begin{array}{l}\mathrm{VI} \\
(\%)\end{array}$ & $\begin{array}{l}\text { Den } \\
(\%)\end{array}$ & $\begin{array}{l}\text { VI } \\
(\%)\end{array}$ & $\begin{array}{l}\text { Den } \\
(\%)\end{array}$ & $\begin{array}{l}\mathrm{VI} \\
(\%)\end{array}$ & $\begin{array}{l}\text { Den } \\
(\%)\end{array}$ & $\begin{array}{l}\mathrm{VI} \\
(\%)\end{array}$ \\
\hline $\begin{array}{l}\text { Brosimum guianense } \\
\text { (Aubl.) Huber ex Ducke }\end{array}$ & Moraceae & 1.38 & 3.06 & 2.11 & 4.12 & 2.45 & 4.62 & 2.43 & 4.88 \\
\hline $\begin{array}{l}\text { Casearia arborea } \\
\text { (Rich.) Urb. }\end{array}$ & Salicaceae & 2.21 & 3.99 & 3.32 & 5.75 & 1.22 & 4.08 & 2.81 & 5.93 \\
\hline $\begin{array}{l}\text { Myrcia splendens (Sw.) } \\
\text { DC. }\end{array}$ & Myrtaceae & 2,09 & 4,48 & 6,37 & 10,58 & 7,02 & 10,79 & 4,34 & 7,64 \\
\hline $\begin{array}{l}\text { Casearia javitensis } \\
\text { Kunth }\end{array}$ & Salicaceae & 1.16 & 3.35 & 5.05 & 7.57 & 4.48 & 6.86 & - & - \\
\hline $\begin{array}{l}\text { Tapirira guianensis } \\
\text { Aubl. }\end{array}$ & Anacardiaceae & 1.99 & 6.57 & 1.78 & 5.65 & 1.62 & 4.36 & - & - \\
\hline $\begin{array}{l}\text { Dialium guianense } \\
\text { (Aubl.) Sandwith }\end{array}$ & Fabaceae & 0.95 & 8.52 & 0.59 & 4.08 & 0.87 & 5.01 & - & - \\
\hline Ocotea Iongifolia Kunth & Lauraceae & 0.88 & 3.96 & 5.96 & 18.55 & 4.38 & 14.93 & - & - \\
\hline $\begin{array}{l}\text { Cochlospermum } \\
\text { orinocense (Kunth.) } \\
\text { Steud. }\end{array}$ & Bixaceae & 3.30 & 11.8 & 1.88 & 8.57 & - & - & 1.21 & 10.10 \\
\hline $\begin{array}{l}\text { Deguelia spruceana } \\
\text { (Benth.) AMG Azevedo }\end{array}$ & Fabaceae & 1.92 & 5.43 & - & - & - & - & 1.97 & 4,00 \\
\hline $\begin{array}{l}\text { Hymenaea parvifolia } \\
\text { Huber }\end{array}$ & Fabaceae & 0.38 & 6.78 & - & - & - & - & 1.44 & 6.52 \\
\hline $\begin{array}{l}\text { Annona exsucca (DC.) } \\
\text { A.DC. }\end{array}$ & Annonaceae & 0.76 & 3.00 & - & - & - & - & 1.36 & 5.46 \\
\hline $\begin{array}{l}\text { Siparuna guianensis } \\
\text { Aubl. }\end{array}$ & Siparunaceae & 5.22 & 7.03 & - & - & 2.45 & 3.81 & - & - \\
\hline Casearia silvestris Sw. & Salicaceae & - & - & 2.01 & 4.63 & 1.55 & 3.69 & 1.90 & 4.16 \\
\hline
\end{tabular}


Table 1. Continuação

\begin{tabular}{|c|c|c|c|c|c|c|c|c|c|}
\hline \multirow[b]{2}{*}{ Species } & \multirow[b]{2}{*}{ Family } & \multicolumn{2}{|c|}{$\mathrm{CF}$} & \multicolumn{2}{|c|}{ SF } & \multicolumn{2}{|c|}{ MF } & \multicolumn{2}{|c|}{ LF } \\
\hline & & $\begin{array}{r}\text { Den } \\
(\%)\end{array}$ & $\begin{array}{l}\mathrm{VI} \\
(\%)\end{array}$ & $\begin{array}{l}\text { Den } \\
(\%)\end{array}$ & $\begin{array}{l}\mathrm{VI} \\
(\%)\end{array}$ & $\begin{array}{r}\text { Den } \\
(\%)\end{array}$ & $\begin{array}{l}\mathrm{VI} \\
(\%)\end{array}$ & $\begin{array}{r}\text { Den } \\
(\%)\end{array}$ & $\begin{array}{l}\mathrm{VI} \\
(\%)\end{array}$ \\
\hline $\begin{array}{l}\text { Protium heptaphyllum } \\
\text { (Aubl.) Marchand }\end{array}$ & Burseraceae & - & - & 3.86 & 7.52 & 2.39 & 4.94 & 2.28 & 4.35 \\
\hline $\begin{array}{l}\text { Hevea brasiliensis } \\
\text { (Willd. ex Juss.) Müll. } \\
\text { Arg. }\end{array}$ & Euphorbiaceae & - & - & 0.60 & 4.26 & 1.23 & 5.45 & - & - \\
\hline $\begin{array}{l}\text { Lacmellea arborescens } \\
\text { (Mull.Arg.) Markgr. }\end{array}$ & Apocynaceae & - & - & 3.76 & 6.66 & 2.19 & 4.30 & - & - \\
\hline $\begin{array}{l}\text { Byrsonima spicata } \\
\text { (Cav.) Rich. ex Kunth }\end{array}$ & Malpighiaceae & - & - & 0.70 & 4.63 & - & - & 0.60 & 4.95 \\
\hline Eugenia citrifolia Poir. & Myrtaceae & - & - & 2.12 & 4.22 & - & - & 2.58 & 5.62 \\
\hline Cecropia palmata Willd. & Urticaceae & 4.58 & 5.91 & - & - & - & - & - & - \\
\hline $\begin{array}{l}\text { Chamaecrista } \\
\text { apoucouita (Aubl.) Irwin } \\
\text { \& Barneby }\end{array}$ & Fabaceae & 1.14 & 4.91 & - & - & - & - & - & - \\
\hline $\begin{array}{l}\text { Cupania scrobiculata } \\
\text { L.C.Rich. }\end{array}$ & Sapindaceae & 1.80 & 3.18 & - & - & - & - & - & - \\
\hline $\begin{array}{l}\text { Ecclinusa lanceolata } \\
\text { (Mart.\& Eich.ex Miq.) } \\
\text { Pierre }\end{array}$ & Spotaceae & 0.81 & 2.83 & - & - & - & - & - & - \\
\hline Inga lateriflora Miq. & Fabaceae & 2.23 & 4,00 & - & - & - & - & - & - \\
\hline $\begin{array}{l}\text { Lindackeria paludosa } \\
\text { (Benth.) Gilg. }\end{array}$ & Achariaceae & 1.78 & 4.01 & - & - & - & - & - & - \\
\hline $\begin{array}{l}\text { Mabea angustifolia } \\
\text { Spruce ex Benth. }\end{array}$ & Euphorbiaceae & 4.18 & 6.03 & - & - & - & - & - & - \\
\hline $\begin{array}{l}\text { Solanum } \\
\text { distichophyllum Sendth. }\end{array}$ & Solanaceae & 5.31 & 6.26 & - & - & - & - & - & - \\
\hline $\begin{array}{l}\text { Aspidosperma } \\
\text { multiflorum A.DC. }\end{array}$ & Apocynaceae & - & - & 0.15 & 3.65 & - & - & - & - \\
\hline $\begin{array}{l}\text { Mezilaurus ita-uba } \\
\text { (Meisn.) Taub. ex Mez }\end{array}$ & Lauraceae & - & - & 1.27 & 4.05 & - & - & - & - \\
\hline $\begin{array}{l}\text { Miconia crassinervia } \\
\text { Cogn. }\end{array}$ & Melastomataceae & - & - & 1.83 & 3.51 & - & - & - & - \\
\hline $\begin{array}{l}\text { Sclerolobium } \\
\text { paniculatum Vogel }\end{array}$ & Fabaceae & - & - & 0.92 & 4.86 & - & - & - & - \\
\hline Simarouba amara Aubl. & Simaroubaceae & - & - & 1.31 & 5.58 & - & - & - & - \\
\hline $\begin{array}{l}\text { Eschweilera obversa } \\
\text { (0.Berg) Miers }\end{array}$ & Lecythidaceae & - & - & - & - & 1.44 & 5.91 & - & - \\
\hline $\begin{array}{l}\text { Glycydendron } \\
\text { amazonicum Ducke }\end{array}$ & Euphorbiaceae & - & - & - & - & 0.88 & 3.77 & - & - \\
\hline Guatteria foliosa Benth. & Annonaceae & - & - & - & - & 1.20 & 4.41 & - & - \\
\hline $\begin{array}{l}\text { Maprounea guianensis } \\
\text { Aubl. }\end{array}$ & Euphorbiaceae & - & - & - & - & 1.57 & 5.90 & - & - \\
\hline $\begin{array}{l}\text { Matayba inelegans } \\
\text { Radlk. }\end{array}$ & Sapindaceae & - & - & - & - & 3.54 & 5.09 & - & - \\
\hline $\begin{array}{l}\text { Sacoglottis } \\
\text { matogrossensis Malme }\end{array}$ & Humiriaceae & - & - & - & - & 0.37 & 3.77 & - & - \\
\hline $\begin{array}{l}\text { Swartzia recurva } \\
\text { Poepp. }\end{array}$ & Fabaceae & - & - & - & - & 1.56 & 4.48 & - & - \\
\hline
\end{tabular}


Table 1. Continuação

\begin{tabular}{|c|c|c|c|c|c|c|c|c|c|}
\hline \multirow[b]{2}{*}{ Species } & \multirow[b]{2}{*}{ Family } & \multicolumn{2}{|c|}{$\mathrm{CF}$} & \multicolumn{2}{|c|}{ SF } & \multicolumn{2}{|c|}{$\mathrm{MF}$} & \multicolumn{2}{|c|}{ LF } \\
\hline & & $\begin{array}{l}\text { Den } \\
(\%)\end{array}$ & $\begin{array}{l}\mathrm{VI} \\
(\%)\end{array}$ & $\begin{array}{l}\text { Den } \\
(\%)\end{array}$ & $\begin{array}{l}\mathrm{VI} \\
(\%)\end{array}$ & $\begin{array}{l}\text { Den } \\
(\%)\end{array}$ & $\begin{array}{l}\mathrm{VI} \\
(\%)\end{array}$ & $\begin{array}{l}\text { Den } \\
(\%)\end{array}$ & $\begin{array}{l}\mathrm{VI} \\
(\%)\end{array}$ \\
\hline $\begin{array}{l}\text { Cordiera myrciifolia } \\
\text { (K.Schum) Pers. \& } \\
\text { Delprete }\end{array}$ & Rubiaceae & - & - & - & - & - & - & 3.95 & 4.75 \\
\hline Croton cajucara Benth. & Euphorbiaceae & - & - & - & - & - & - & 3.95 & 4.75 \\
\hline Eugenia patens Poir. & Myrtaceae & - & - & - & - & - & - & 1.21 & 4,00 \\
\hline $\begin{array}{l}\text { Geissospermum } \\
\text { argenteum Woodson }\end{array}$ & Apocynaceae & - & - & - & - & - & - & 2.13 & 3.81 \\
\hline $\begin{array}{l}\text { Abarema mataybifolia } \\
\text { (Sand.) Barneby \& Irwin }\end{array}$ & Fabaceae & - & - & - & - & - & - & 1.67 & 7.30 \\
\hline $\begin{array}{l}\text { Bocageopsis multiflora } \\
\text { (Mart.) R.E.Fries }\end{array}$ & Annonaceae & - & - & - & - & - & - & 0.98 & 4.08 \\
\hline $\begin{array}{l}\text { Lecythis pisonis } \\
\text { Cambess. }\end{array}$ & Lecythidaceae & - & - & - & - & - & - & 1.06 & 6.01 \\
\hline $\begin{array}{l}\text { Warszewiczia coccinea } \\
\text { (Vahl) Klotzsch }\end{array}$ & Rubiaceae & - & - & - & - & - & - & 2.35 & 3.50 \\
\hline Xylopia frutescens Aubl. & Annonaceae & - & - & - & - & - & - & 3.80 & 7.70 \\
\hline Total 1 (20 species) & & 43.49 & 104.2 & 45.66 & 115.38 & 42.39 & 107.0 & 43.30 & 108.80 \\
\hline Total 2 (Other species) & & 56.51 & 195.8 & 54.34 & 180.97 & 57.61 & 192.9 & 56.70 & 191.20 \\
\hline Total (\%) & & 100 & 300 & 100 & 300 & 100 & 300 & 100 & 300 \\
\hline
\end{tabular}

significant differences in the three DBH classes between FF and $\mathrm{CF}$, with $57 \%$ and $63 \%$ of all individuals, respectively, being in the first size class $(1.27-5 \mathrm{~cm} \mathrm{DBH})$. The frequency of the second class decreased dramatically to $23 \%$, while for the third it was approximately $10 \%$. These three size classes comprised some $97 \%$ of individuals (Figure 4), leaving only about 3\% for the other eight classes. Species with notably higher DBH included Hymenaea parvifolia Huber $(139.73 \mathrm{~cm})$, Duguetia echinophora Chorus. $(117.77 \mathrm{~cm})$ and Aspidosperma multiflorum A.DC. $(111.40 \mathrm{~cm})$. A t-test comparison showed that mean $\mathrm{DBH}$ was similar between $\mathrm{FF}$ and $\mathrm{CF}(\mathrm{FF}=7.03$; $\mathrm{CF}=7.09, \mathrm{t}=0.11, \mathrm{df}=32, \mathrm{p}=0.9131)$, suggesting that $\mathrm{FF}$ and $\mathrm{CF}$ are structurally similar, both a developing forest and a "mature" forest comprising many thin individuals.

Multiple linear regression showed that the effect of predictive variables, FF area $\left(\mathrm{F}_{\mathrm{A}}\right)$ and sampled area $\left(\mathrm{S}_{\mathrm{A}}\right)$, lacked a defined relationship with the structural variable mean $\mathrm{DBH}\left(\mathrm{DBH}_{\mathrm{M}}\right)$ of FF, while distance to $\mathrm{CF}\left(\mathrm{D}_{\mathrm{CF}}\right)$ had a negative relationship, as indicated by the adjustment of the equation: $\mathrm{DBH}_{\mathrm{M}}=7.395-0.00614^{*} \mathrm{~F}_{\mathrm{A}}-0.0003 * \mathrm{D}_{\mathrm{CF}}+$ $0.00064^{*} S_{\mathrm{A}}\left(r^{2}=0.53 ; \mathrm{F}_{21,3}=7.85, P=0.0011\right)$ (Figure 5). For the effect of the predictive variables on total basal area $\left(T_{B A}\right)$, the multiple linear regression showed that the predictors $F_{A}$ and $S_{A}$ had, respectively, negative and positive relationships with the dependent variable, while $\mathrm{D}_{\mathrm{CF}}$ showed

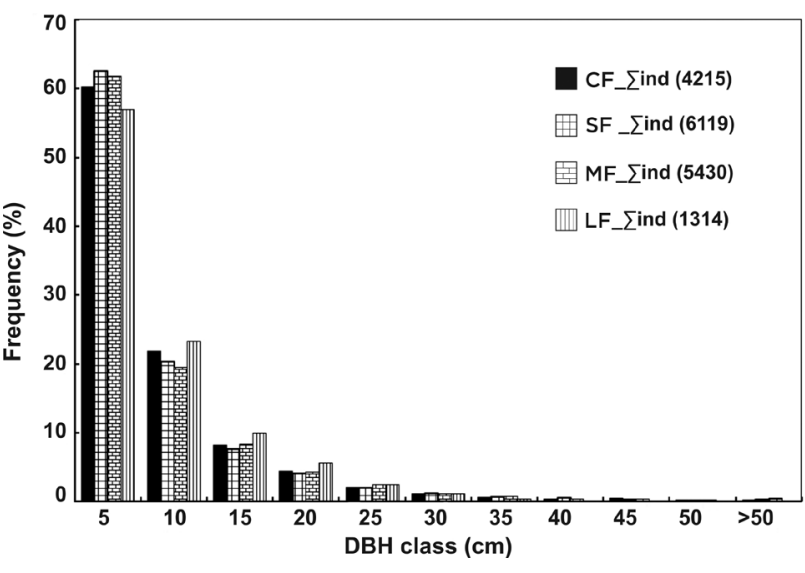

Figure 4. Grouping of individuals by DBH classes $(\geq 1.27 \mathrm{~cm})$, in forest fragments and continuous forest in Alter do Chão, with the respective percentages for individuals in each class.

no apparent relationship with $\mathrm{T}_{\mathrm{BA}}\left(\mathrm{T}_{\mathrm{BA}}=-0.9654-0.0109 * \mathrm{~F}_{\mathrm{A}}\right.$ $0.000016^{*} \mathrm{D}_{\mathrm{CF}}+0.002873^{*} \mathrm{~S}_{\mathrm{A}} ; r^{2}=0.53, P=0.0011$ ) (Figure 6).

Cluster analysis indicated the presence of two groups (GI and GII). GII was homogeneous, composed only of samples from FF, all close to each other, close to Verde Lake and the Tapajós River (Figure 7). The floristic composition within GI was more variable, forming three subgroups (GI.1, 
GI.2 and GI.3), with similarity percentages ranging from 30 to $57 \%$, except for CF72 that had a similarity value at the $25 \%$ limit. The first subgroup, GI.1, consisted primarily of continuous-forest samples (70\%), but there were three fragments (FF17.1, FF32 and FF40), especially FF32 and FF40, that were closer to the continuous forest area. The second, GI.2, was composed entirely of fragments and had similarity values that ranged from 45 to $57 \%$, of which four were very close to bodies of water, and two were distant from the others, but near continuous forest and water bodies. The third, GI.3, was formed by three fragments that were all close to each other and two continuous-forest samples. Except for the CF72 sample in GI.3, similarity values for fragments and other continuous-forest samples exceeded $30 \%$.

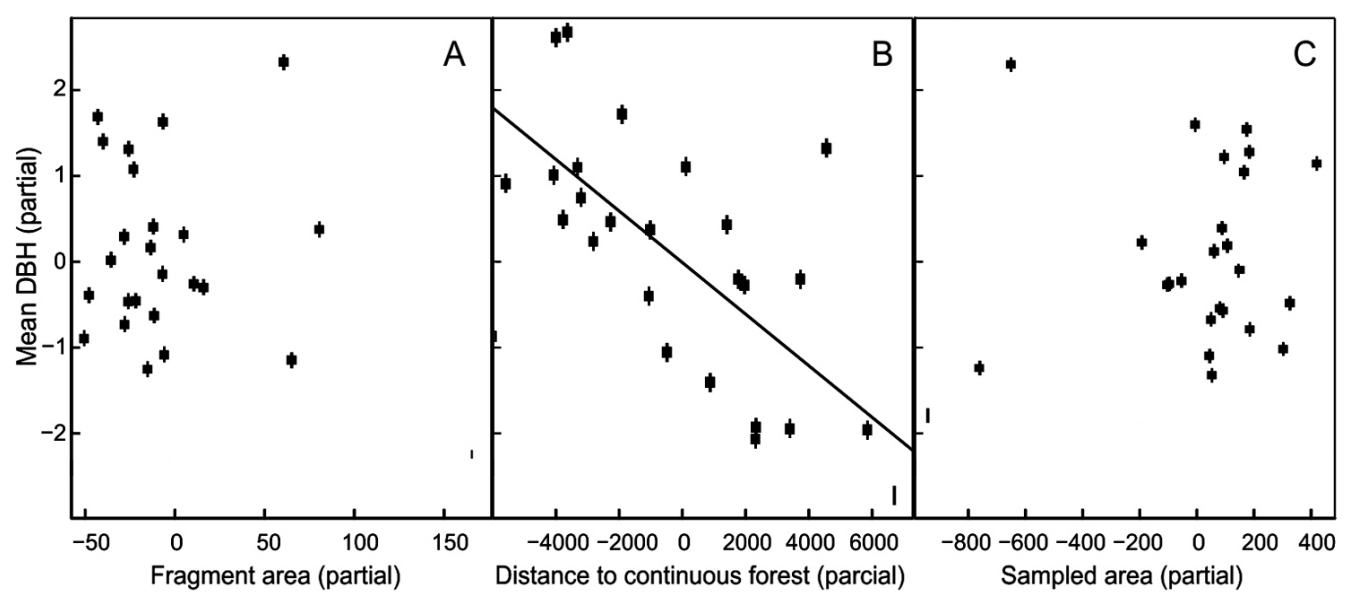

Figure 5. Partial regression plots of mean $\mathrm{DBH}\left(\mathrm{DBH}_{\mathrm{M}}\right)$ on forest fragment area $\left(\mathrm{FF}_{\mathrm{A}}\right)$, sampled area $\left(\mathrm{S}_{\mathrm{A}}\right)$ and distance to continuous forest $\left(\mathrm{D}_{\mathrm{CF}}\right)$ of forest fragments sampled in Alter do Chão.

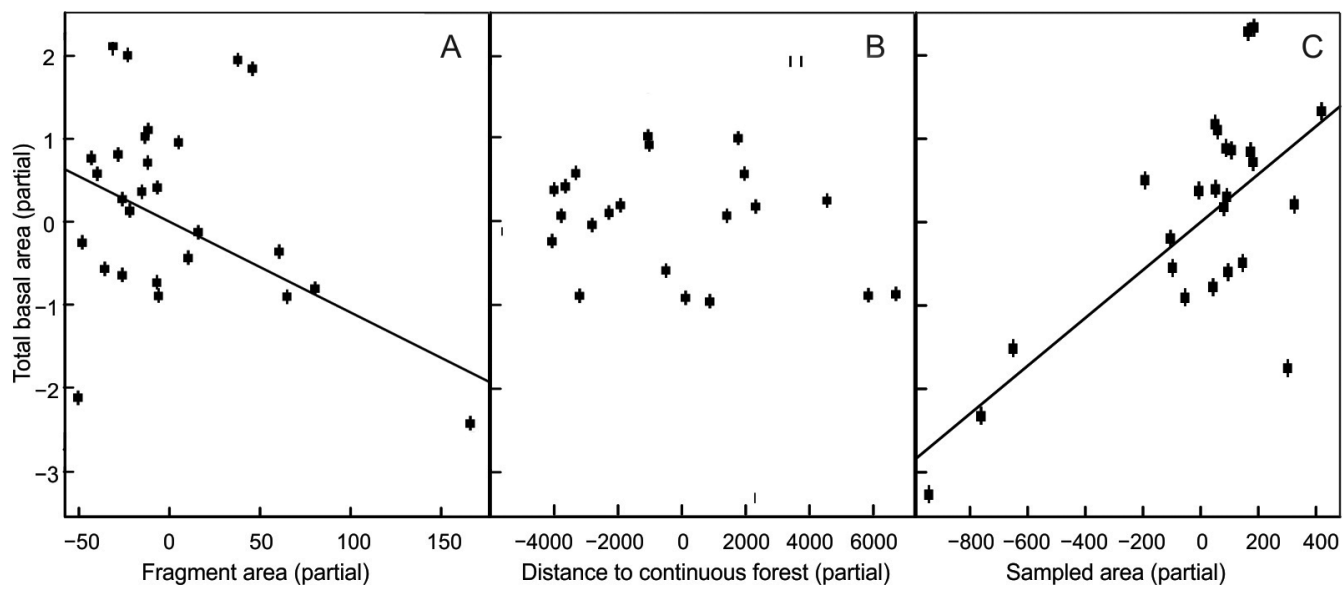

Figure 6. Partial regression plots of total basal area $\left(T_{B A}\right)$ on forest fragment area $\left(\mathrm{FF}_{\mathrm{A}}\right)$, sampled area $\left(\mathrm{S}_{\mathrm{A}}\right)$ and distance to continuous forest $\left(\mathrm{D}_{C F}\right)$ of forest fragments sampled in Alter do Chão. 


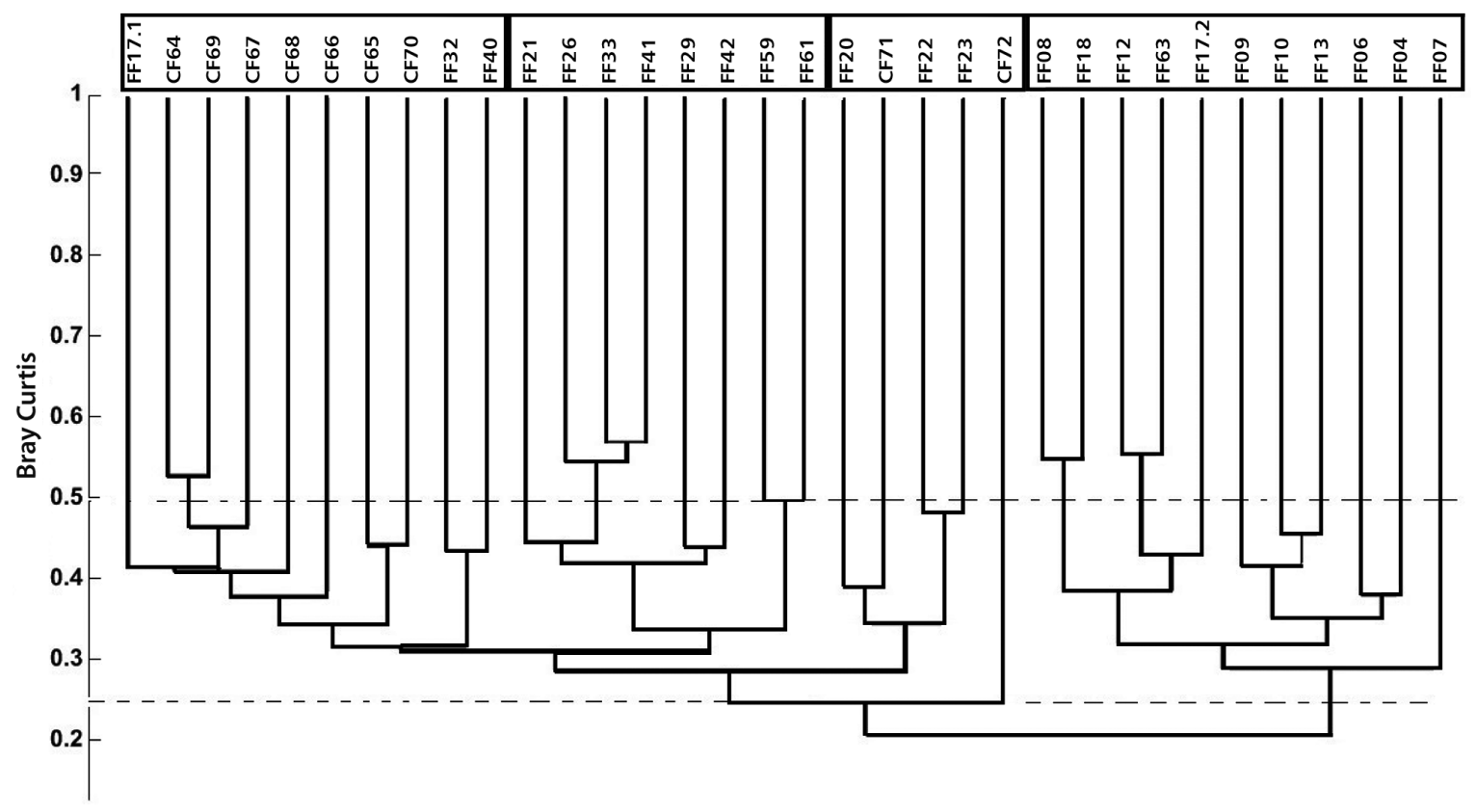

Figure 7. Cluster analysis dendrogram (UPGM), based upon Bray-Curtis similarity indices, for FF and CF sample sites in Alter do Chão, showing the groups and subgroups derived by the analysis.

\section{DISCUSSION}

Myrtaceae, Fabaceae, Salicaceae, Sapindaceae, Euphorbiaceae and Lauraceae were the most abundant families. These taxa are always present whenever native floras are sampled in the Amazon (Matos and Amaral 1999). Indeed the Fabaceae always appears among the three most abundant families in the Amazon (ter Steege et al. 2006 and 2013), both in old (Santos et al. 2013) and recent forest fragments (Rankin-de-Merona et al. 1992), as well as various types of forests. In studies using $\mathrm{DBH} \geq 10 \mathrm{~cm}$, Fabaceae is considered hyperdominant, with other families are not part of hyperdominant groups because most of their individuals are small and thin (ter Steege et al. 2013).

The abundance of Myrtaceae in forest fragments has also been reported for the Atlantic Forest (Oliveira-Filho and Fontes 2000, Durigan et al. 2008), which shows both the great range of this family and/or the capacity of its members to adapt to fragmented areas, since there are large differences between the Amazon and Atlantic Forest biomes. Fabaceae had the greatest species richness, and it is commonly cited as the richest family in other Amazon forest types (Pitman et al. 2002, Oliveira et al. 2004, ter Steege et al. 2013). Myrtaceae and Fabaceae were considered by Miranda et al. (2002) as the richest families in forest areas within the Roraima savannas, while Santos et al. (2013) cited Fabaceae as the most abundant and richest family in forest fragments from Boa Vista savanna in the central Brazilian Cerrado. Their fruits being a food source for medium- and large-sized frugivores, which facilitates dispersal (Catharino et al. 2006), can explain their presence in both secondary and mature forest. Thus, in the Alter do Chão fragments, the abundance and species diversity of many families do not differ from other forest types, even when isolated from continuous forest.

Trees are the predominant plant life form in tropical forest, and in the current study. Even using smaller DBH ranges, where more variation in life forms can occur, our results did not differ from other investigations that used higher $\mathrm{DBH}$ boundaries, where trees are the dominant life (rather than, e.g. shrubs or lianas). According to Maas and Westra (1993), of the 292 plant families in neotropical forests, 140 contain tree species. This is the dominant biological type, accounting for about $80 \%$ of individuals with $\mathrm{DBH} \geq 10 \mathrm{~cm}$.

Many widely-distributed tropical forest species tend to be locally abundant in some areas and relatively rare in others (Hubell and Foster 1986). This can be seen, in the current study, with Ocotea longifolia, Casearia javitensis and Myrcia splendens. All these had large numbers of individuals in both FF and CF, unlike the most abundant species in most areas of Amazon forest, such as Eschweilera spp. and Pouteria spp.

The phytosociological organization of FF and CF groups showed that the 20 species with the highest IV 
were numerically similar, showing that the most influential parameter was abundance. High density of species tends to be typical for the region (Araújo et al. 2009). In the 47 species set derived from the 20 most abundant species in FF and CF sites, 41 appear in the general lists of species in both analyzed environments. Species considered superabundant were those that had the highest IV, both in FF and CF, showing the influence of abundance in phytosociological structuring. The number and size of sampling units used (Balduino et al. 2005) probably explain this pattern, in part.

As in other types of tropical forests, the majority of individuals were concentrated in the first $\mathrm{DBH}$ class in both FF and CF. This characteristic of native tropical forests indicates a positive balance between recruitment and mortality, and is characteristic of self-regenerating vegetation assemblages (Silva Júnior 1999). Almost all individuals were concentrated in the first three size classes, showing that the local forest is composed of thin individuals and that FF and CF are structurally similar. Despite the selective exploitation of the environment by the local people, the large number of individual plants indicates that their component species are not vulnerable to extinction. Apart from Mezilaurus ita-uba, which occurs in several DBH classes $(1.27$ to $40.42 \mathrm{~cm})$, the upper classes were occupied by only three individuals and, as the species has great commercial value, these may be subject to local extinction.

In our study, trees were recorded in all $11 \mathrm{DBH}$ classes, indicating that, structurally, FF and CF forests are probably mature, stable and highly likely to continue perpetuating their constituent species. The smallest diameter trees $(1.27-5 \mathrm{~cm}$ $\mathrm{DBH})$ were twice as abundant as in the second size class $(5.0$ $\mathrm{cm}>\mathrm{DBH} \leq 10.0 \mathrm{~cm}$ ), and five times more abundant than in the third size class, showing the ecological importance of small-trees in the structure, diversity and biomass to tropical forests (Memiaghe et al. 2016).

Our study suggests that isolation of forest fragmentation influences mean DBH in fragments. However, there is a limit to the form of this relationship (Navarrete and Menge 1997). A possible explanation is that the distance of smaller fragments from the continuous forest influences the fragments assemblage structure, possibly due to reduction in habitat quality.

Muller-Dubois and Ellenberg (2003) proposed that, for two areas to be considered alike, they must have at least $25 \%$ of species in common. Based on this criterion, cluster analysis revealed high similarity levels among our sampling sites. While the lowest similarities obtained were between samples CF72 and FF07, the remaining comparisons revealed similarity values greater than $33 \%$. In Bray-Curtis index value calculations, the outcome of the groupings can be influenced by the abundances of species. Similarity in species composition occurs when the analysis is focused on the same type of vegetation (Rodrigues and Nave 2000). In the GI.1 subgroup, the observed similarity was mostly influenced by the 25 most abundant species that made up the subset, and the distances between samples varied from 30 to $53 \%$, with FF near to CF and the largest fragment. One of the factors that influenced the grouping was fragment size and isolation: two were very close, while others were distant from each other, indicating that distance is an aggregation factor (Kuntz et al. 2009). Four fragments with extreme distributions - two in the north and two adjacent in the south of the study area - had a species composition of 28 dominant species. For the GI.3 subgroup, the smallest grouping came from a large fragment (FF20), which was similar to CF71 (41\%), so that this fragment was compositionally more like an area of continuous forest. The floristic distinctions within the GI group may be due to the influence of soil factors of hydrogeomorphological and/or anthropogenic origin (Kuntz et al. 2009).

In group GII, formed only by fragments, similarity ranged from 27 to 59\%, and the distance was the most important factor to influence similarity, since all component FF were close to each other and distant from the CF. Fragment size was also important since only one (FF17-2) was considered to be of large size and most of the others were small. Proximity to each other and to water bodies, and isolation from CF appeared to be the factors that most influenced group composition, despite environmental factors usually having the greatest influence on species groupings (Cottenie 2005).

\section{CONCLUSION}

Despite their long history of isolation, the Alter do Chão forest fragments still support a significant proportion of the continuous forest species assemblage. Most of the species present in the fragments belong to Seasonally Semideciduous and Dense Terra Firme Forest, corroborating the notion that floristic composition and similarity were little changed, being at an advanced succession stage. DBH distribution patterns showed that both the forest fragments and continuous forest are at a mature stage. Some of the locally most abundant species recorded in this qualitative and quantitative study appear on the 2008 IBAMA list of vulnerable species. However, we urge caution when considering directories of endangered species, especially those that occur in the Amazon, where there are many areas that have had few or no collections. The species listed were common at Alter do Cháo, and we have found them frequently in other places in the Amazon. Basing conservation priorities only on these lists may not be a useful strategy.

\section{ACKNOWLEDGMENTS}

The study had support from a PPD-PPG7 (European Union /MCTI/INPA) grant to Dr. Renato Cintra, the 
Brazilian Program for Biodiversity Research (PPBio) and the National Institute for Biodiversity Research in the Amazon (CENBAM). Thanks to Dr. Maria de Lourdes da Costa Soares for original text correction and comments. Dr. Douglas Daly identified the Burseraceae specimens, and Dr. Luciano Paganucci the Fabaceae. In addition, we thank Mr. Jose Ribeiro and Jakes Camara da Costa, who helped with data collection and species identification. Adrian Barnett helped with the English.

\section{REFERENCES}

Albernaz, A.L.K.M. 2001. Zoneamento de regiāo de Alter do Chão, Pará: Um exercício de planejamento para uma unidade de conservaçâo de uso direto. Doctoral thesis. Instituto Nacional de Pesquisas da Amazônia/Universidade Federal do Amazonas, Manaus, Amazonas. 132p.

Araújo, R. A.; Costa, R.B.; Felfili, J.M.; Gonçalvez, I.K.; Sousa, R.A.T.M.; Dorval, R. 2009. Florística e estrutura de fragmento florestal em área de transição na Amazônia Matogrossense no município de Sinop. Acta Amazonica, 39: 865-878.

Bates, H.W. 1892. A naturalist on the river Amazonas. Murray, London. S/N.

Balduino, A.P.C.; Souza, A.L.; Meira Neto, J.A.A.; Silva, A.F.; Silva Júnior, M.C. 2005. Fitossociologia e análise comparativa da composição florística do Cerrado da flora de Paraopeba - MG. Revista Árvore, 29: 25-34.

Bray, J.R.; Curtis, J.T. 1957. An ordination of the upland forest communities of southern Wisconsin. Ecology Monographs, 27: $325-349$.

Catharino, E.L.M.; Bernacci, L.C.; Franco, G.A.D.C.; Duringan, G.; Metzger, J.P. 2006. Aspecto da composição e diversidade do componente arbóreo das florestas da Reserva Florestal do Morro Grande, Cotia, São Paulo. Biota Neotropica 6: bn00306022006. (htpp://www.biotaneotropica.org.br/v6n2/pt/abstract? article+ bn00306022006). , Accessed on 12Feb2016)

Cavalcanti, D.; Tabarelli, M. 2004. Distribuição de plantas amazônico-nordestinas no centro de endemismo Pernambuco: Brejos de altitude versus Florestas de terras baixas. In: Porto, K.C.; Cabral, J.J.P.; Tabarelli, M. (Ed.). Brejos de altitude em Pernambuco e Paraíba. Ministério do Meio Ambiente, Brasília, p.285-296.

Cerqueira, R.; Brant, A.; Nascimento, M.T.; Pardini, R. 2003. Fragmentação: alguns conceitos. In: Rambaldi, D.M.; Oliveira, D.A.S. (Org.). Fragmentaçâo de Ecossistemas: Causas, efeitos sobre a biodiversidade e recomendaçôes de politicas públicas. Brasília: MMA/SBF. 100 p.

Climate Data.org. Clima de Alter do Chão (http://climate-data.org/ location/317494). Accessed on 23/05/2014.

Constantino, R.; Britez, R.M.; Cerqueira, R.; Espindola, E.L.G.; Grelle, C.E.V.; Lopes, A.T.L.; et al. 2003. Causas da fragmentação: Naturais. In: Rambaldi, D.M, Oliveira, D.A.S (Org.). Fragmentação de Ecossistemas: Causas, efeitos sobre a biodiversidade e recomendaçôes de politicas públicas. Brasilia: MMA/SBF. ISBN - 87166-48-4. 100 p.
Cottenie, K. 2005 Integrating environmental and spatial processes in ecological community dynamics. Ecology Letters, 8: 1175-1182.

Durigan, G.; Bernacci, L.C.; Franco, G.A.D.C.; Arbocz, G. F.; Metzger, J.P.; Cathrino, E.L.M. 2008. Estádio sucessional e fatores geográficos como determinantes da similaridade florística entre comunidades florestais no Planalto Atlântico, Estado de São Paulo, Brasil. Acta Botânica Brasileira, 22: 51-62.

ESRI. 1996. ArcView GIS, version 3.1. Environmental Systems Research Institute, Redlands, CA.

Flora do Brasil 2020 ( under construction). Jardim Botânico do Rio de Janeiro. Available in http://florado brasil.jbrj.gov.br. Accessed on $12 / 10 / 2016$ to $01 / 15 / 2017$.

Hammer, O. Haper, D.A.T.; Rayn, P.D. 2001. PAST: Paleontological Statistic Software Package for Education and Data Analysis. Paleontologia Electronica, 4:1-9 (http://palaeo-electronica. org/2001_1/past/issue1_01.htm). Accessed on 20May2014.

Huber, O.; Stefano, R.D.; Aymard, G.; Riina, R. 2006. Flora and vegetation of the Venezuelan Llanos: A Review. In: Neotropical savannas and seasonally dry forests: plant diversity, biogeographic and conservation. Taylor \& Francis, Boca Raton. p.95-120.

IBGE. 2012. Manual Técnico da Vegetação Brasileira: Sistema fitogeográfico. Inventário das formaçōes florestais e campestres Técnicas e manejo de coleçôes botânicas. Procedimentos para mapeamentos. No $1,2^{\text {a }}$ Edição ampliada. Centro de Documentação e Disseminação de Informações, Rio de Janeiro, $271 \mathrm{p}$.

IBAMA. 2008. Instrução Normativa $n^{\circ} 6$, disposto no artigo 27, parágrafo $6^{\circ}$ da $n^{\circ} 10.683$, em 28/05/2003. Ministério do Meio Ambiente. Brasilia, DF.

Kindt, R.; Coe, R. 2005. Tree diversity analysis: A manual and software for common statistical methods for ecological and biodiversity studies. World Agroforestry Centre (ICRAF), Nairobi, 207p.

Kuntz, S.H.; Ivanauskas, N.M.; Martins, S.V.; Silva, E.; Stefanello, D. 2009. Análise de similaridade florística entre florestas do alto rio Xingu, da bacia amazônica e do planalto central. Revista Brasileira de Botânica, 32: 725-736.

Maas, P.J.M.; Westra, L. 1993. Neotropical plant families. Koeltz Scientific Books, Koenigstein, Germany, 200 p.

Magnusson, W.E.; Lima, A.P.L.; Albernaz, A.L.K.M.; Sanaiotti, T.M.; Gillaumet, J-L. 2008. Composição florística e cobertura vegetal das savanas na região de Alter do Chão, Santarém, Pa. Revista Brasileira de Botânica, 1: 165-177.

Matos, F.D.A.; Amaral, I.L. 1999. Análise ecológica de um hectare em floresta Ombrófila de Terra- Firme, Estrada da várzea, Amazonas, Brasil. Acta Amazonica, 23: 365-379.

Meniaghe, H.R.; Lutz, J.A.; Korte, L.; Alonso, A.; Kenfack, D. 2016. Ecological importance of small-diameter trees to the structure, diversity and biomass of a tropicsl evergreen forest at Rabi, Gabon. PloS ONE,11: e0154988

Miranda, I.S. 1993. Estrutura do estrato arbóreo do cerrado amazônico em Alter do Chão, Pará, Brasil. Revista Brasileira de Botânica, 16: 143-150. 
Miranda, I.S.; Absy, M.L.; Rebêlo, G.H. 2002. Community structure of woody plants of Roraima Savannahs, Brazil. Plant Ecology, 164: 109-123.

Müeller-Dombois, D.; Ellemberg, H. 2003. Aims and methods for vegetation ecology. John Wiley \& Sons, New York, 547p.

Navarrete, S.A.; Menge, B.A. 1997. The body size-population density relationship in tropical rocky intertidal communities. Ecological Monographs, 66: 557-566.

Oliveira, A.N.; Amaral, I.L.; Ramos, M.B.P.; Nobre, A.D.; Couto, L.B.; Sahdo, R.M. 2004. Composição e diversidade florísticaestrutural de um hectare de floresta densa de terra firme na Amazônia Central, Amazonas, Brasil. Acta Amazonica, 38: 627-642.

Oliveira-Filho, A.T.; Fontes, M.A.L. 2000. Patterns of floristic differentiation among Atlantic forests in southeastern Brazil and the influence of climate. Biotropica, 32: 793-810.

Peters C, Gentry AH, Mendelsohn RO. 1989. Valuation of an Amazonian rainforest. Nature, 339: 655-656.

Pitman, N.C.A.; Terborgh, J.W.; Silman, M.R.; Nuñez, P.V.; Neill, D.A.; Cerón, C.E.; Palacios, W.A.; Aulestia, M. 2002. A comparison of tree species diversity in two upper Amazonian forests. Ecology, 83: 3210-3224.

Prado, D.E. 2000. Seasonally dry forests of tropical South America: from forgotten ecosystems to a new phytogeographic unit. Edinburgh Journal of Botany, 57: 437-461.

Rankin-de-Merona, J.; Prance, G.T.; Hutchings, R.W.; Silva, M.F.; Rodrigues, W.A.; Vehling, M.E. 1992. Preliminary results of a large-scale tree inventory of upland rain forest in the Central Amazon. Acta Amazonica, 22: 493-534.

R Core Team. 2014. R: A language and environment for statistical computing. R Foundation for Statistical Computing, Vienna, Austria. (http://www.R-project.org/). Accessed on 13May2015.

Rodrigues, R.R.; Nave, A.G. 2000. Heterogeneidade florística das matas ciliares. In: Rodrigues, R.R.; Leitão-Filho, H.F. (Ed.). Matas ciliares: conservação e recuperação. Edusp/Fapesp, São Paulo, p.45-71.
Sanaiotti, T.M.; Martinelli, L.A.; Victoria, R.L.; Tumbore, S.E.; Camargo, P.B. 2002. Past vegetation in Amazon savannas: determined using Carbon isotopes of soil organic matter. Biotropica, 34: 2-16.

Santos, N.M.C.; Vale Jr, J.F.; Barbosa, I. 2013. Florística e estrutura arbórea de ilhas de mata em áreas de savana do norte da Amazônia brasileira. Boletim do Museu Paraense Emílio Goeldi, 8: 205-221.

Serena, M. 1984. Distribution and habitats of parthenogenetic and sexual Cemidophorus lemniscatus, Sauria:Teiidae, in Surinam. Copeia, 3: 713-719.

Sette-Silva E.L.S. 1997. A vegetação de Roraima. In: Barbosa, R.I.; Ferreira, E.J.G.; Castellōn, E.G. (Eds.). Homem, ambiente e ecologia no estado de Roraima. Instituto Nacional de Pesquisas da Amazônia, Manaus. p.401-415. ISBN 85-211-0008-6.

Silva Júnior, M.C. 1999. Composição florística, fitossociologia e estrutura diamétrica na mata de galeria do Monjolo, Reserva Ecológica do IBGE (RECOR), DF. Boletim do Herbário Ezechias Paulo Heringe, 4: 30-45.

Soares, C.P.B.; Paula Neto, F.; Souza, A.L. 2007. Dendrometria e inventário florestal. Ed. UFV, Viçosa, MG. 276p.

Tabarelli M; Silva, J.M.C.; Gascon, C. 2004. Forest fragmentation, synergisms and the impoverishment of neotropical forests. Biodiversity and Conservation, 13: 1419-1425.

ter Steege, H.; Pitman, N.C.A.; Phillips, O. L.; Chave, J.; Sabatier, D.; Duque, A. et al. 2006. Continental-scale patterns of canopy tree composition and function across Amazonia. Nature, 443: 444-447.

ter Steege, H.; Pitman, N.C.A.; Sabatier, D.; Baraloto, C.; Salomão, R.P.; Guevara, J.E. et al. 2013. Hyperdominance in the Amazonian Tree Flora. Science, 342: 1243092-1 -1243091-9.

Received: $14 / 07 / 2016$

Accepted: 16/12/2016 